\title{
Caught between scylla and charybdis? assessing the practice of journalism in Bamenda-Cameroon during the anglophone crisis, 2016-2019
}

\begin{abstract}
A casual observation of journalistic practices around the world reveals deep-seated abuses on journalists and media organizations. While this is a universal state of affair, the situation in Africa is particularly dire due to poor democratic practices and human rights situations. In Cameroon, abuses on journalists and media organizations prevail and have often been blamed on government actors. However, with the advent of the Anglophone Crisis in 2016, a non-state actor emerged to compliment government actions against the free practice of journalism in Bamenda, Capital of the country's North West Region. From this background, this paper contends that, since the emergence of armed pro-separatist groups (known as 'Amba' Boys) in Cameroon's Anglophone Regions of the North West and South West within the framework of the Anglophone Crisis, journalists in and around Bamenda suffered serious infringements on their rights from two mutually opposing groups (including government actors on the one hand and armed separatist groups on the other). The paper analyses written sources, interviews, newspaper articles, internet sites as well as field observations to demonstrate that media men and women in Bamenda suffered abuses ranging from threats, arrests, torture, kidnapping, imprisonment and suspension from both government and 'Amba' Boys within this period. The paper is synchronized in thematiccum-chronological synthesis to sustain logic.
\end{abstract}

Keywords: scylla, charybdis, anglophone crisis, abuses on journalism, Bamenda
Volume 3 Issue 6 - 2019

Reymond Njingti Budi
Doctorandus, The University of Bamenda, Cameroon

Correspondence: Reymond Njingti Budi, Doctorandus, The University of Bamenda, Cameroon, Email budzi5@yahoo.com

Received: September 21, 2019 | Published: November 18, 2019

\section{Introduction}

Journalism plays a pivotal role in every society. In fact, the cutting-edge role journalists play in society assigns them a delicate responsibility of either making or marring the society in which they operate. Journalism is thus a very powerful but at the same time delicate profession. Journalists possess the power to maintain stability in society or to disrupt it. Speaking from this background, Roosevelt ${ }^{1}$ avers that, The power of the journalist is great, but he is entitled neither to respect nor admiration because of that power unless it is used aright. He can do, and often does, great good. He can do, and often does, great mischief... Offenses against taste and morals, which are bad enough in a private citizen, are infinitely worse if made into instruments for debauching the community through a newspaper. The journalist then possesses the power to stir the direction of public discourse. ${ }^{2}$ It follows that the journalist, by virtue of the role he plays in society contributes greatly to its political, economic and social evolution. Before the advent of the social media and the growth of Citizen Journalism, the traditional journalist virtually monopolized the right to information. Whatever the traditional journalist said was determinant to the functioning of the society and was usually taken seriously by its members. There is little wonder that many societies considered journalism as the Forth Estate in governance. Increasingly, a free press symbolized a free society with advanced democratic practices and vice versa. Journalists however also faced great challenges especially in times of Crisis.

Journalism has been defined as the process of gathering, processing and disseminating news and information to an audience. ${ }^{3}$
Far from conventional belief that journalism deals with 'gathering' and 'disseminating' information, the special verve of the journalist is his/her ability to process/treat information before disseminating. The process of treating information before dissemination requires that the journalist is imbued with a high standard of objectivity which is a key element in journalism. Journalists must therefore be objective and this is what makes their profession distinct from the current phenomenon of social media practice where most often than not, objectivity has been sacrificed on the altar of subjective reporting. However, according to Deuze, ${ }^{4}$ although objectivity has a problematic status in current thinking about the impossibility of value-neutrality, academics and journalists alike revisit this value through synonymous concepts like 'fairness', 'professional distance', 'detachment' or 'impartiality' to define and re-legitimize what media practitioners do. The journalist is always in an incessant search for objectivity in his/her reporting and this indeed is a huge task. ${ }^{5}$ Objectivity helps to keep journalism alive as it remains its ideological cornerstone. ${ }^{4}$ Personal feelings, ideological inclinations and beliefs have however often dazzled the view of the journalist from an objective posture. Apart from these internal factors (from standpoint of journalist), external factors have also been determinant to the journalists' quest for objectivity. While the quest for objectivity in journalism remains an ongoing stride, a number of factors have conspired to make objectivity in journalism a mirage. This has resulted to subjective narratives flooding the media especially in the developing countries. For journalists to be objective, government policy and other external considerations towards the press must be favorable. Weaver ${ }^{6}$ captures this in the following statement; Reporters across the globe feel that their work can only thrive and flourish in a society that protects its media from censorship; in a 
company that saves its journalists from the marketers; in a newsroom where journalists are not merely the lackeys of their editors; and at a desk where the journalist is adequately supported through, for example, further training and education. Not only is this enabling environment always lacking for journalistic practice but sometimes the journalists' attempt to be objective is misconstrued as complicity and this is often the case during crisis period involving opposing camps. The case of Cameroon since the advent of the Anglophone Crisis is glaring. Journalists that made efforts to be objective were sometimes tagged with complicity either by the government or by the secessionist armed groups and subsequently became targets of threats, molestations, kidnappings, arrests and even imprisonment. ${ }^{7}$ The Crisis period is thus a difficult period for journalists to practice altogether.

The Swedish Emergency Management Agency (SEMA) in its Crisis Communication Handbook in 2008 hold that 'the art of communication is difficult. And communicating in the midst of a crisis is even more difficult than everyday interaction. The intermediaries are many, and the risk of rumors and misunderstandings is great' ${ }^{8}$ At no other period does the journalist face difficulty in his/her practice as in a crisis situation. In other words, while journalistic practice is usually exposed to victimization, it is even more so during crisis period. Journalists' rights are violated with impunity and in case of armed conflicts; journalists are usually caught in between. This has been the experience of many a journalist in and around Bamenda in Cameroon since the advent of the Anglophone Crisis in 2016. In brief, the practice of journalism during the Crisis could be likened to a venture between the Scylla and the Charybdis as journalists most often had it difficult to report since any news item either favored one of the conflicting parties or the other thereby exposing them to the wrath of the disfavored party. The main thrust of this paper is therefore to demonstrate the difficulty journalists have been exposed to from both the government and the separatist groups in Bamenda-Cameroon since the advent of the Anglophone Crisis in 2016. However, it is worth considering the historical and legal background to journalistic practice in Cameroon in the debut section of the study.

\section{Historico-legal contexts of journalistic practice in Cameroon}

Cameroon's checkered history and the judicial environment have greatly influenced the evolution of its press. In fact, the Cameroonian press is a product of its historical and legal environment. Gallagher ${ }^{9}$ has argued and strongly too that; Contemporary journalism in Cameroon is a phenomenon strongly influenced by the pattern of the nation's past. High and low points in quantity and quality of journalistic output have corresponded to periods of crisis, regime changes, and the whims of those in power. This is a succinct description of the practice of journalism in Cameroon. This profession has greatly been influenced by the country's history as well as national and international legal instruments. Though the journalistic practice began in the country as far back as the $1900 \mathrm{~s},{ }^{9}$ colonialism and postindependent politics also greatly shaped the evolution of journalistic practice in Cameroon. A remarkable feature of the Cameroonian press is its bicultural background which was directly the result of the country's history. Following the collapse of German Kamerun (18841916) after the ensued 1914-1916 Carnage, the territory fell under the League of Nations Mandate ' $\mathrm{B}$ '. The League thus placed the territory under the administration of Britain and France after the partition which gave rise to British Cameroon (English-Speaking) and French Cameroon (French-Speaking). The administration of the partitioned Cameroon passed from the Mandate of the League of Nations (1922-
1939) through the Trusteeship of the United Nations (1946-1961) to Reunification which took place on October 1, 1961. Thus before the reunification of Cameroon in 1961, the two parts of the country had known different administrations for over forty-five (45)years. The earliest press organs in Cameroon were founded and ran by missionary bodies who used newspapers to "teach the norms and values of the 'new civilization' being introduced to the local tribes... and also encouraged the people to respect and serve the colonial authority". 9 The press was firmly in the hands of the colonial authorities who used it to promote their interest in the territory. As such private press was virtually inexistent and the government (colonial) interests as spelled out in the press went unchallenged. The masses therefore got just one side of the story.

However, a new wave of journalistic practice which took an antigovernment form began to appear in Cameroon during the period of French Mandate in the 1920s. ${ }^{9}$ This happened with the emergence of a cream of Cameroonian press men at home and abroad who used the press to challenge colonial administration. This view is captured by Professor Nga Ndongo ${ }^{10}$ when he posits that the press became a "means of expression, a weapon for the colonized Blacks, and in the final analysis, played a role in the integration of the dominated African masses". A typical example of such indigenous press organ was the Mbale ('The Truth') which was operated by French Cameroonians in France and became so critical of the French administration in Cameroon. Consequently, the paper was systematically shut down in 1929 and the journalists dispersed by the French government who felt uncomfortable and edgy with the truths uncovered by the paper. ${ }^{9}$ It is thus evident that as far back as the colonial period, the Cameroonian press was placed in a situation of difficulty and attempts were rife to hinder the free practice of the press. This phenomenon invariably spilled over into the post-independent era and further compounded by the emergence of the Anglophone Crisis in 2016. During the period of the Trusteeship in Cameroon (1946-1960/61), the press was caught in the whirlpool of nationalist politics which culminated in independence and reunification. In the midst of the hectic political maneuvers, the press became more vocal and coordinated. Political pluralism were reflected in a corresponding explosion in the number of press organs particularly newspapers. Many press organs were directly linked to the political opinions expressed by the existing parties. Like Ekoudi ${ }^{11}$ points out clearly, "of the 71 newspapers that came and went in this period, at least 40 were attached directly to one of the 91 political parties in the country". Besides the fact that most political parties ran press organs particularly newspapers as propaganda instruments, journalists were also politically active and engaged in political party activities. In British Southern Cameroons, for instance, one of the earliest political parties to articulate the option for Integration with Nigeria, the Kamerun People's Party (KPP) was led by Nerius Namaso Mbile who was a journalist. This period therefore tremendously brought the press to the limelight of the country's political evolution. Incidentally, both the political parties that ran press organs and pressmen that ran political parties were usually in the opposition. This most often than not brought them at odds with the ruling government and saw their rights seriously abused.

Ostensibly, while the practice of journalism in French Cameroon was seriously controlled and censored by the French administration who generally felt apprehensive towards the press, it practice in British Cameroons was largely liberal based on the Anglo-Saxon tradition. The practice of journalism in Southern Cameroons was regulated by the Nigerian Newspaper Ordinance No. 10 of 1903 which was further amended by the Nigerian Newspaper Ordinance 
No. 40 of 1917, the Newspaper Ordinance No. 26 of 1941 and the Eastern Nigerian Law of $1955 . .^{12}$ After reunification, the West Cameroon Newspaper Ordinance was passed to regulate the operation of newspapers in the territory. Following the reunification, the French media regulatory instrument based on the 1959 Law with it repressive tendencies were imposed on the Southern Cameroonians which led to some protests which heightened in mid-1966. ${ }^{12}$ This invariably precipitated the passage Law No. 66/LF/13 of December 21, 1966 by the Cameroon Federal Assembly. It is worth mentioning that, after independence and reunification in 1961, both parts of Cameroon coalesced into the Federal Republic of Cameroon ${ }^{1}$ under President Ahmadou Babatoura Ahidjo. Even though the Federal Constitution stated that 'The Federal Republic of Cameroon shall be democratic, secular and $[. .$.$] proclaims its adherence to the fundamental freedoms$ set out in the Universal Declaration of Human Rights and the Charter of the United Nations', ${ }^{13,14}$ from 1962, President Ahidjo began taking measures that were intended to dampen the journalistic verve that had been kindled in the country during the period of nationalist political activism. In his words, Gallagher ${ }^{9}$ captures Ahidjo's attempt to gag the press as follows; ... in June 1962 the government under Ahmadou Ahidjo began tightening its hold on all opposition, including the press. No legal changes were implemented but several journalists were arrested, and what became known as the "law of silence" dampened the nation's previous enthusiasm for newspapers.

Government's attempts to muzzle the press especially those that were very critical of government actions became a common phenomenon in post-independent Cameroon. At first blush, this phenomenon took place amidst the proliferation of media organs like Radio and TV Stations and Newspapers in the country. To achieve the aim of gag ordering the press, the President of the Federal Republic of Cameroon resorted to the passage of the first ever Press Law in postindependent Cameroon in December 1966. ${ }^{2}$ This Law was amended five (5) times between 1969 and 1981 by Decree No. 69/LF/13 of November 1969, by Decree No. 73/6 of December 1973, by Decree No. $76 / 27$ of December 14, 1976, by Decree No. 80/18 of July 14, 1980 and Decree No. 81/244 of June 22, 1981. ${ }^{12}$ The 1966 Press Law and its amendments generally imposed administrative, financial and territorial surveillance ${ }^{12}$ which formed the basis of the muffling of the Cameroonian press. In actual fact, as summarized in the following statement, the press was subject to strict censorship by government departments.

The text of the law, modeled on similar French laws, begins, 'Liberty of the press is guaranteed throughout the territory of the Federal Republic of Cameroon', but then adds, 'This liberty is exercised within the limits of the provisions of the present law'. Article 11 of this law required editors to give two copies of their final

${ }^{1}$ Following the Reunification of the two Cameroons in 1961, the country opted for a Federal system of government. The former British Southern Cameroons became the West Cameroon State while the former French Cameroon became the East Cameroon State. Cameroon remained a Federal Republic until 1972 when the Federation was dissolved after a referendum in favor of a Unitary system of government by President Ahidjo. What became known as the Anglophone Problem in Cameroon was usually traced to this phenomenal event that exposed the Anglophones to marginalization by removing the constitutional safeguards that the Federal constitution afforded them.

${ }^{2}$ It may be worth mentioning at this juncture that one of the reasons for the passage of the 1966 Press Law in Cameroon was the desire by the government of President Ahidjo to harmonize the Dual press regimes that drew from the Common Law system in Southern-West Cameroon and the Civil Law in French-East Cameroon. proofs or their finished paper to the office of the Minister of Territorial Administration (MINAT) and the local prefect four hours before publication or distribution. MINAT had the right to censor or suspend any material of a seditious nature or anything that was considered contrary to morality. All new publications had to be authorized by MINAT before distributing their first issue. Violation of this law was punishable by fine, imprisonment, and/or seizure of printed copies. Its strictness prompted journalists to dub it 'the penal code of the press'. As a result of this Law, the number of newspapers in Cameroon dropped from thirty (30) to Nine (9) within a period of five (5) years until the creation of the Societé de Presse et d'Editions du Cameroun (SOPECAM) and its newspaper, Cameroon Tribune in 1974. The 1970s saw the growth of the press in Cameroon once again but this time, most of the papers were pro-government.

The year 1972 saw a remarkable change in the legal frame work of the country. This was following the constitutional change that took place after the May 20, 1972 Referendum in which Cameroonians voted in favor of a unitary system of government. As a result, the constitution was changed and a unitary constitution was adopted. In spite of the constitutional change, the constitution, in its preamble reiterated its desire to uphold the principles of freedoms. It stated that; We the people of Cameroon [...] Affirm our attachment to the fundamental freedoms enshrined in the Universal Declaration of Human Rights, the Charter of United Nations and the African Charter on Human and Peoples' Rights and all duly ratified international conventions relating thereto, in particular, to the following principles: [...] the freedom of communication, of expression, of the press, of association, and of trade unionism, as well as the right to strike shall be guaranteed under the conditions fixed by law. ${ }^{15}$ It is no doubt that the leverage given by this constitution contributed to growth of the press in Cameroon in the 1970s. The press however, was still being strictly controlled by the government and this explains why most of the press organs that sprang up during this period were pro-government.

The rise of Paul Biya to power in 1982 launched a new phase of press freedom in the country. Apparently, the Biya administration followed in the footsteps of Ahidjo in efforts to contain the free practice of the press in Cameroon. The main difference however was that press censorship took place amidst a perceptible impression that there was free press while journalists repeatedly complained of government efforts to place limits on their practice. Nyamnjoh ${ }^{16}$ captures the new phenomenon in the following words; for a couple of years after November 1982 the press was free, as long as it was freedom to criticize Ahidjo and his regime. For as soon as the very press attempted a more critical look at the present [Biya] government and situation, the clampdown was firm, leading to far more arrests and detentions of media practitioners than were ever carried out by the previous regimes. (Emphasis is mine). There were evidences that the Biya regime was also high-handed in the handling of the press in Cameroon though this happened in a more subtle manner. President Biya had rubricated his rule as the New Deal and presented himself as a veritable purveyor of democracy to the nation. Under President Biya, the Television was introduced in Cameroon in 1985 and this necessitated the passage of Law No. 87/19 of December 17, 1987 which was directed at regulating audio-visual communication in the country. ${ }^{12}$ Generally, this Law saw audio-visual communication as purely a government utility as it did not envisage any future involvement of private individuals in that sector.

As part of his democratization impulse, President Biya passed Law No. 90/052 of December 19, 1990 related to the promotion of a wide 
range of freedoms in the country. These freedoms included freedom of communication. Its emphasis on the promotion of different freedoms earned it the sobriquet of "Liberty Laws". Radio communication was liberalized and private radios were springing up in great numbers, particularly in Yaoundé, Douala and Bamenda as from the 2000s when the law took effect. There were also rural radios geared towards support for community development projects. The written press was also diversified. Apart from opening up the media landscape to private press, the Law also simplified the process of setting up a press organ in the country by scrapping off the administrative, financial and territorial requirements for publishing newspapers. It also extended the freedom to communicate to the audio-visual medium as well. All these meant that the Law was an improvement of the former legal instruments that regulated journalism practice in the country. In spite of this, the free practice of journalism in Cameroon under Paul Biya still left much to be desired. The reaction of the government towards the free practice of journalism after 1990 seemed to suggest that the government took the form of a proselytizer to democracy in Cameroon but refused the power inherent in same. This explains why journalists continued to face challenges including arrests and detentions, threats, suspension and even closure of media organs through the National Communication Council (NCC), the government-created media regulatory organ.

Another constitutional twist took place in Cameroon in 1996 and also affected the practice of the press. The 1996 Constitution which came into force, like the previous constitutions once again maintained the government's position as far as the respect for basic freedoms was concerned. In its preamble, the Constitution also emphasized the promotion of all kinds of freedoms including freedom of communication. ${ }^{15}$ This constitutional provision still did not deter government's efforts to muzzle the press in the country. Censorship of the press became common and journalists and press organs became the ultimate victims of harassments, arrests, threats, imprisonment and even deaths. Cameroon also signed a number of international conventions for the promotion freedom of press and for advancement of human rights. Some of these include the United Nations Charter, the Universal Declaration of Human Rights, The International Covenant on Civil and Political Rights and its optional protocol (ratified June 27, 1984), and the African Charter on Human and Peoples' Rights among others. The latter instrument is even more articulate as far press freedom is concerned. The African Charter on Human and Peoples' Rights was adopted by the eighteenth $\left(18^{\text {th }}\right)$ Conference of Heads of State and Government of the Organization of African Unity (OAU), held in Nairobi from June 24 to 27, 1981 and entered into force on October 21, 1986. Cameroon signed and ratified it on July 23, 1987 and June 20, 1989 respectively. The ratification instruments were deposited on September 18, 1989. Pursuant to Article 65 of the Charter, it came into effect in Cameroon on December 18, 1989. In so doing, Cameroon had expressed its unwavering desire to lift its people to a political, moral, economic, social and cultural level respectful of human dignity. Article 9 of the Charter stipulates that: "Every individual shall have the right to receive information [...]" and that "Every individual shall have the right to express and disseminate his opinions within the law". ${ }^{17}$ This article of the Charter invariably informed the government's commitment in ensuring the free practice of the press in Cameroon through the various constitutional frameworks as seen above. However, the effective implementation of some of these instruments remains a misapprehension.

The foregoing discussion not only spotlights the historico-legal context of journalistic practice in Cameroon but also demonstrates that the main counter factor to the free practice of journalism since the Mandate period was from within the ranks of the government. However, this situation changed since 2016 with the escalation of the Anglophone Crisis. Journalists and their media organs were caught in a dilemmic situation where they either fell to the wrench of the government structures put in place to control the free practice of journalism or to the wrath of the separatist groups in the North West Region. For better comprehension, we must attempt a brief highlight on the Anglophone Crisis in Cameroon.

\section{The anglophone crisis and the practice of journalism}

Cameroon has recently been stunned by a wave of quaking developments largely from within the ranks of the Anglophone community (and/or those who imbibe their values and sympathize with them) that have trapped the entire Nation. This was the escalation of violent protests from among the English-speaking communities of the North West and South West Regions. The curtain raiser to this movement was the meeting of the Common Law Lawyers in Bamenda-Cameroon in May 2015. Shortly after, the South West Chiefs meeting in Kumba under the Chairmanship of the Chief Senator Nfon VE Mukete (Oldest member of Senate) seemed to have articulated grievances more or less the same as those of the Common Law Lawyers that passed earlier. Then the Lecturers of the University of Buea (First Anglo-Saxon State University) also raised concerns on attempts to submerge the Anglo-Saxon traditions of that State University. And then, the crusade by the Honorable Awudu Cyprian Mbaya, Member of Parliament for the Donga Mantung Constituency against what he termed the "linguistic marginalization" of Anglophones as testified by writings on Bill-boards, sign-posts and other placards on public establishments like hotels, ministerial departments, and road signs just to name but these. These issues culminated in the strikes of the Common Law Lawyers from October 2016 and then the Anglophone Teachers under the coordination of Teacher Trade Unions including Higher Education Teachers' Syndicate (SYNES), Cameroon Teachers' Trade Union (CATTU), Teachers' Association of Cameroon (TAC), Baptist Teachers' Trade Union of Cameroon (BATTUC), Presbyterian Education Authority Teachers' Trade Union (PEATTU) and Catholic Education Workers' Trade Union (CEWOTU) from November 21, 2016. This was followed by waves of sporadic demonstrations especially in Bamenda and Buea among the youths, University students of Buea, Motor Bike riders, taxi drivers and traders. Meanwhile attempts to resolve the issue through dialogue seemed far-fetched thus leading to calls for the return to federalism and ultimately, secession and independence of the Southern Cameroons territory. These events that began manifesting from November 2016 was a result of accumulated grievances among the Anglophones in Cameroon who since reunification in 1961 and the putting in place of the Unitary system of government in 1972 felt marginalized administratively, economically, politically and even socially.

By 2017, the Anglophone Question became violent with the emergence of armed groups to defend the course of the Anglophones especially secession and independence and the creation of the State of Ambazonia. Consequently, the armed groups that emerged became known as "Amba" Boys and perpetuated attacks on military, government facilities especially schools, government officials and the blockading and destruction of roads and bridges linking the various towns of the North West and South West Regions of the country. Interestingly, journalists also played a significant role in the escalation of the crisis. A case in point was Mancho Bibixy (a journalist) who 
took advantage of the strikes initiated by teachers and lawyers of the North West and South West Regions to launch his "Coffin Revolution" in Bamenda in December 2016. In the midst of this deadlock, journalists and unarmed civilians who chose neutrality and/ or either supported one of the camps also became targets. Worse of all, the armed separatist groups opted for 'No Schools' in the affected Regions while the government on her part was bent on seeing the effective resumption of schools in these Regions. Thus, journalists who advocated for back-to-school became targets of the separatist groups and if they joined in calling for 'No Schools' until a lasting solution was sought for the Anglophone issue, they were clamped down by the government as they were accused of complicity with the secessionists. Journalists and media organizations had become victims in the intensifying crisis.

\section{Abuses on journalists during the anglophone crisis}

The advent of the Anglophone Crisis in Cameroon saw journalists being pushed to a tight corner and victimized by both government agencies and separatist groups in the North West Region of Cameroon. It may be worth mentioning that just at the exordium of the Crisis in 2016, the Minister of Communication had written to Journalists to stop all roundtable discussions concerning the political atmosphere in the country. It went without saying that the Minister's missive was to become a snare for journalists in these Regions throughout the period of the Crisis. On the basis of the Minister's injunction, journalists and media organs began to bear the brunt of practicing during the Crisis period. One of the earliest media organizations to suffer pillory from government was Radio Hot Cocoa (RHC), a popular private media outlet in Bamenda. Radio Hot Cocoa was temporarily suspended by the Senior Divisional Officer (SDO) for Mazam, Pierre Rene Songa on January 10, 2017. ${ }^{18}$ According to reports on the suspension, "Radio Hot Cocoa [was] temporarily suspended for talking about the Anglophone Problem of Cameroonians in Southern Cameroons ... that their program 'Biggest Breakfast Show' [was] fueling the crisis in Bamenda". ${ }^{19}$ The temporary ban on the radio was however later lifted on January 12, 2017 by the Chairman of the National Communication Council (NCC), Peter Essoka but was not allowed to broadcast its program, 'Biggest Breakfast Show' (BBS) which was anchored by Brenda Kiven and Jude Mbaku. ${ }^{20}$

About a year later, precisely on January 23, 2018, Peter Tabit Chi, a Pidgin English news host at the same radio station was suspended for a period of three (3)months by the NCC of Peter Essoka. ${ }^{21}$ Though the reasons were not given as to why the journalist was suspended, some opined that the journalist's vocal stance on the Anglophone Crisis earned him the suspension by the NCC. ${ }^{21}$ More precisely, at the height of the Crisis in the North West Region, there seemed to emerge popular opinions among the citizens that the Head of State should visit Bamenda and speak to the people as a means of minifying tensions. This elicited social media rumors announcing the coming to Bamenda of the Head of State. Peter Tabit Chi is said to have related the rumors on his radio program which earned him the sanction. ${ }^{22}$ Thus from the beginning of the Crisis, it promised to be a difficult one for journalists especially in and around Bamenda.

Another victim of government clampdown on journalists during the period of the crisis was George Tanko Tarlusi, the Manager of Savannah Frontier Radio (SFR) in Ndu Sub Division of DongaMantung Division of the North West Region of Cameroon. George Tanko Tarlusi recounts the bitter tale of his experience in Ndu before his abscond to Nigeria due to fear of death threats. He intimates that; As the crisis deepened, the Divisional Officer (DO) of Ndu
Sub Division began considering me for arrest due to the fact that my radio aired programs related to the crisis. While the DO visibly showed antipathy to my person as well as to the radio, I received lifethreatening messages from unknown individuals and even attempts to attack me in my house. Worse still, when the Governor visited Ndu Sub Division to assess the level of schools resumption following the signing of communique lifting the ban on schools by the teachers' trade unions on February 5, 2017, I was there to cover the visit. But more and more, the DO's animus towards me increased as he personally reported me and my radio to the Governor for fuelling the Crisis through our programs. It became evident that I could be arrested or even killed at any one moment. To save my life, I had to abandon the practice and to escape to Nigeria where I now find solace. ${ }^{23}$

It should be noted that SFR was patronized by Honorable Cyprian Awudu Mbaya, one of the Social Democratic Front (SDF) Opposition Members of Parliament from the Donga/Mantung Constituency. Tarlusi himself was a local youth leader of the Opposition SDF Party. On the basis of these, local administrative authorities saw the radio as a possible threat to government action in the area through its critical programs. As the crisis mounted, it became clear that it only sufficed to identify with the SFR in Ndu in any way to be marked for arrests or threatened with death. Eventually, people who identified with the radio station by way of participating in it debates or being guests on it programs were systematically dispersed by threats of arrests and killing. This was the case with Henry Lamnyam who thought was a teacher also served as a freelance journalist at the same radio station. Lamnyam was particularly vocal about issues concerning Southern Cameroons and especially, the Anglophone Question in Cameroon. When the Crisis ensued, the Divisional Officer (DO) for Ndu exploited the opportunity offered by the Crisis and the fact that Lamnyam often participated in radio programs on SFR to settle differences he had with him over Church leadership by earmarking him for arrest. ${ }^{24}$ This forced him to also escape for his life to Nigeria. On the other hand, Martin Fon Yembe of the Renaissance Community Radio (RCR) in Ndu who was also very critical of government action and a staunch supporter of the federalist (and later secessionist) stance eventually died in Ndu purportedly from tear gas suffocation on October 2, 2017. ${ }^{3}$ His anti-government position and his radical stance in favor of the Anglophone course made it difficult for the family to secure an authorization for his evacuation for medical attention in nearby Kumbo town following the government-imposed state of emergency of October 1, 2017.

The death of Martin Fon Yembe was seen by many as the height of abuses on journalists by government or its agents during the Crisis. A linguist and journalist by training, Fon Yembe served as First Deputy Mayor of Ndu Council and an astute member of the Opposition SDF political party, rights defender and teacher and also belonged

\footnotetext{
${ }^{3}$ It is worth mentioning that October 1, 2017 was crucial in the escalation of the Anglophone Crisis in Cameroon. This day has often been a cause for confrontation between the government forces and pro-secessionist Southern Cameroonians because on October 1, 1961, Southern Cameroons gained independence from Britain and Reunified with the Republic Cameroon following the latter's independence on January 1, 1960. With the escalation of the crisis, Southern Cameroonian activists threatened to declare their independence on that day in 2017. To stop any such manifestation, the government instituted a State of Emergency which was characterized by restrictions in movements from one town to another. Yembe is said to have taken ill on this day and since there was no possibility to move, coupled with the fact that he was not in good terms with the DO who could issue an authorization for his evacuation for medical attention, he died in Ndu.
} 
to many journalist associations including Cameroon Association of English Speaking Journalists (CAMASEJ) North West Chapter, Cameroon Union of Journalists (CUJ), Commonwealth Journalist Association among others. ${ }^{25}$ His family accused government forces of masterminding his death. ${ }^{25}$ Margerate Yembe, his sister insisted that Fon Yembe hosted a Radio Program on SFR on Saturday September 30, 2017 in which he made this statement relating to the crisis and the rising tension in view of October 1. He said; Good evening and welcome to Savannah Frontier Radio, FM 92.0...cooling the tension, feel at home, while the tension's rising, lower your temperature...my name is Martin Luther Shey Lontum, the messenger of the people, as the BIR guys invade Ndu, electricity has disappeared, so we give you electricity through our collection, what else can we do, what will be will be.... at this critical moment we will be discussing issues at stake with everyone instilling fear in one another...who is frightening who? [In view of October 1], Nobody should be violent, just act like what you did on September 22, do not scatter anything, just march and greet the chiefs then go and have your drinks...we will not accept anybody cross our land and cause chaos...we want peace, we want justice and above all, we want freedom. ${ }^{26}$

After this radio program, Fon Yembe was visited by two security forces in his apartment in Ndu. ${ }^{26}$ The next day October 1, Fon Yembe took ill and was hospitalized at a Health Center in Ndu. This invariably was a result of the molestation he suffered in the hands of the two security forces the previous night. ${ }^{26}$ However, his life, perhaps would have been spared if he was given authorization to be evacuated for proper medical attention but due to his anti-government stance, the DO delayed the signing of the authorization and Yembe died on Monday, October 2, 2017. Government sources however held that Fon Yembe died from natural circumstances but there is no doubt that his death was connected to his radio outings, his support for the Anglophone course and the Crisis in particular. ${ }^{27}$

Arrests and imprisonment also formed part of the abuses on journalists perpetuated by government. Radio broadcaster, Akumbom Elvis McCarthy, former journalist with Afrique Nouvelle Radio Station and later practicing with Abakwa Radio in Bamenda-Cameroon was arrested on March 20, 2018. According to a report penned down by the Committee to Protect Journalists (CPJ), A military tribunal... ordered that McCarthy, a news broadcaster for Abakwa FM Radio, a privately owned broadcaster based in Cameroon's Bamenda region be remanded in custody for a renewable six-month period while police investigate claims that the journalist aired secessionist propaganda....During questioning, judicial police accused McCarthy of being sympathetic toward the self-proclaimed interim government of Ambazonia in his reporting. ${ }^{28}$

Among the accusations levied on McCarthy, he was arrested because he tried to film police alleged to have been harassing taxi drivers and commuters in Bamenda. ${ }^{28}$ This was not the first McCarthy was being abused in his line of duty. The CPJ further submits that, "in November last year [2017], gendarmeries raided McCarthy's home, beat the journalist and accused him of being an 'Amba terrorist'... his phone, laptop, audio recorder, and cash were seized in the raid". ${ }^{29}$ Whatever the accusations, McCarthy's arrest were undeniably not unconnected to the Anglophone Crisis. However, after close to nine (9) months in detention, McCarthy was later released following the decision by the Head of State to release some 289 people arrested and detained in connection with the Crisis. Though released from detention, what McCarthy has found it difficult to extricate him from has been the tale of sordid prison conditions and experiences. For almost a month after his arrest, he was kept in a small cell in
Bamenda where he shared food, water and toilet with thirty (30) other prisoners, slept on bare floor and used water bottles as pillow (McCarthy, 2019). Even put more bluntly, McCarthy recounts that; My imprisonment experience was horrible. I spent almost a month on a floor... I was persistently going through brutalization in police (custody). I still suffer from toothache that was (beaten) by a security officer while I was in a police cell. No one was allowed to visit me. Even after release from prison, McCarthy lives with the physical scar and psychological trauma generated by his experiences in prison for close to nine (9) months. This however has not deterred him from continuing his journalistic practice especially through the Social Media where he operates a news blog known as "Makatinews". This news blog has remained very critical of government and government actions especially as far as the Anglophone Crisis is concerned.

The abuses on journalists in Cameroon during the period of the Anglophone Crisis also touched on the female practitioners. Female journalists had their fair share of the abuses suffered by journalists in Bamenda during the Anglophone Crisis. A case in point is Nancy Mawe who worked with SFR in Ndu. She argues that as the crisis heightened, it became clear that she could also be arrested in Ndu. This forced her to escape to Bamenda and while there and serving with another private media outlet, Mawe recounts that, "you know [I was] called while I was in Ndu and told I'm a potential prisoner, that I'm being investigated". ${ }^{30}$ Though Mawe could not say exactly what might have been her own crime or what she might have said that led to her being investigated, it was clear that her crime was the fact that she was associated with SFR which was tagged with antigovernment programs and propaganda. Another female journalist that suffered from reporting on the Anglophone Crisis was Mimi Mefo Takambou (Editor of English News Desk of Equinox Television in Douala-Cameroon) in an incident involving the death on October 30, 2018 of an American Baptist Missionary in Bambui, fourteen (14) kilometers from Bamenda. This incident which became known as the 'Mimi Mefo Affair' animated discourse in a wide range of media structures in the country at large. The 'Mimi Mefo Affair' began when Charles Truman Wesco, a 44year-old American Missionary was shot in Bambui gripped by violence as part of the Anglophone Crisis. The journalist's reports accused the government forces of being responsible for the killing of the Missionary when she said, 'the army was responsible for the death of US missionary, Charles Truman Wesco' ${ }^{31}$ This statement led to the arrest of Mimi Mefo on November 7, 2018 and detained at the Douala New Bell Central Prison. She was arraigned at the Douala Military Court for; Dissemination of fake news, news lies likely to harm public authorities or national cohesion, facts provided for and punished under Section 113 of the Criminal Code; insult against constituted bodies and civil servants, incitement to revolt against the Government and Institutions of the Republic, acts provided for and sanctioned by Section 154 of the Criminal Code.

Mimi's case was thus taken seriously by the government of Cameroon which felt that the separatist fighters were responsible for the killing of the Missionary. However, after spending three nights at the detention facility, Mimi was released on Saturday, November 10, $2018{ }^{32}$ All charges against her were immediately and unconditionally dropped by the government. Before the incident that led to her arrest, she had been threatened and intimidated by strange calls and text messages due to her reports on the crisis rocking the North West and South West Regions of Cameroon. Like McCarthy's experience, Mimi's prison experiences were also sordid as she laments, "It was not an experience you'd not wish even for your own enemy". ${ }^{32}$ The Anglophone Crisis had thus been a veritable difficult experience for journalists in Cameroon in general and Bamenda in particular. Apart 
from these cases, Funke further avers that even more journalists have suffered abuses from government during the period of the Anglophone Crisis. He spotlights the case of, Mancho Bibixy who also works at Abakwa FM Radio, [and] has been imprisoned on false news and anti-state charges since December 2017 [and] for hosting a show that was critical of government's marginalization of English speakers... In May, he was sentenced to 15years in prison with Tsi Conrad and Thomas Awah Junior two other journalists charged with false news. ${ }^{33}$

It may be worth mentioning at this juncture that Mancho's case was particular because he was arrested for overtly supporting the Anglophone course and for initiating and leading the "Coffin Revolution' in Bamenda which contributed in radicalizing the movement that began as a peaceful protest by lawyers and teachers. It has almost been established (at least among a cross section of Cameroonian journalists) that abuses on press men had always been initiated and perpetuated by government. While this assertion is arguable, the Anglophone Crisis introduced a non-conventional actor in the abuses of press men in and around Bamenda. This was particularly the separatist armed groups known in the region as 'Amba' Boys who took up arms to defend the course of the Anglophones in Cameroon as the Crisis escalated. These groups also targeted and committed reprehensible abuses on some media men and their outlets. During the crisis therefore, it was clear that journalists were pressed from both ends as 'Human Right Watch report blamed both sides for grave abuses... ${ }^{29}$ In the midst of this, the Committee to Protect Journalists (CPJ) African Program Coordinator, Angela Quintal cried out in defense of journalists in the region by calling on; All parties to the conflict in Cameroon, whether government forces or Ambazonians, should stop targeting journalists and media organizations and allow them to operate safely and without fear of reprisal....the media is not the enemy. Journalists are simply trying to do their jobs by ensuring that citizens are armed with useful information in what has become an increasingly bloody phase in Cameroon's History. ${ }^{29}$

In fact, a journalist told CPJ that, Separatists are threatening us with messages that we are siding with government in our reports as we try to stay neutral or objective in the crisis. On the other hand, any report that seems to be propagating the agenda of the separatists is tantamount to the crime of apologies du terrorisme punishable under the anti-terrorism law of the government. The wedging of journalists and media organs from both ends was a veritable difficult situation which could aptly be described as journalists caught between the Scylla and the Charybdis. Among the media organizations that suffered reprisals from separatist groups was the Sky FM Radio Station, a Community Radio based in Ndu Sub Division, Donga/Mantung Division of the North West Region of Cameroon. The media outlet was set ablaze on August 3, 2018 by suspected separatist fighters. The fire destroyed the building hosting the Radio as well as the Radio Equipment including two transmitters, computers, four (4) recorders, television set and office furniture. The Radio Station was said to have been in favor of effective schools resumption in September 2018 and since the separatists had disapproved of the back-to-school campaign, they decided to raze the media outfit. Before the razing of the Radio House, it had been off air since May 19, 2018 due largely to threats from the separatist groups operating in the area. Though the Radio went off air, this didn't deter separatists from setting it ablaze to show their disapproval for the pro-government stance of the radio. In the most extreme of the accusations levied on the Radio, the "Amba" Boys did not want any radio communiqués from the government to be read on the air waves of the Radio. ${ }^{34}$

Worse still, the Station Manager of Sky FM Radio, Gibip Bernard
Tata was systematically being hunted by the separatist groups in Ndu. 'Amba' Boys reportedly went in search of him in his village, Njimnkang twice. Besides, the Manager reports that 'my name as Manager of Sky FM Ndu has been written alongside others and posted all over town as blacklegs...we went through a lot...though I still cannot understand why they razed the radio when we were off air' ${ }^{34}$ The reasons for his search were obvious, either for abduction or killing. As the threats mounted, Gibip decided to abscond to Yaoundé where he sought refuge. Another victim of abduction allegedly carried out by separatist groups in Bamenda was Ambe McMillian Awah, the President of the Cameroon Association of English speaking Journalists, CAMASEJ, North West Regional Chapter on February 21, 2019 at Foncha Street. ${ }^{35}$ Though Ambe was released after a day in captivity, it was widely speculated that his abduction was related to his pro-federalist stance as well as calls for effective schools resumption in the North West Region bedeviled by the Crisis. The situation of journalistic practice in Bamenda-Cameroon had indeed been atrociously targeted and abused by both government and the separatist groups operating in the area. This situation has put to question the reputability with which press freedom is being pursued in Cameroon. The Cameroonian journalist has since 2016 indeed been caught in a snare that has virtually pushed some out of the profession. ${ }^{36-39}$

\section{Concluding thoughts}

This paper set out to investigate the practice of journalism in Cameroon since the exacerbation of the Anglophone Crisis in 2016. From the outset of the Crisis, journalists in and around BamendaCameroon were exposed to a wide range of abuses from both the government and the separatist groups operating in the Region. The abuses on journalists took place amidst an avalanche of national and international legal instruments duly signed by the Cameroon government. The paper argues that the practice of journalism in Bamenda during the Anglophone Crisis could be likened to a venture between Scylla and the Charybdis as journalists and their media organizations were squeezed from both ends by the conflicting parties. However, the paper proposes that journalism remains an inviolate profession and should be allowed to function unscathed even in crisis situation in line with the national and international legal instruments in place. This is because crisis situations are periods when the hankering for information invariably increases among the masses. Consequently, while journalists must continue with rigor and tenacity the pursuit of objective reporting based on the principles of 'fairness', 'professional distance', 'detachment' and 'impartiality', the onus is on the government and conflicting parties to uphold the inviolability of journalistic profession in Cameroon and the world at large.

\section{Acknowledgments}

None.

\section{Conflicts of interest}

The authors declare that there is no conflict of interest.

\section{Funding details}

None.

\section{References}

1. Roosevelt T. The Man in the Arena. Speech Presented at Sorbonne University, Paris. 1910.

2. Connections. The Role of Journalism in Society. MediaLit Moments. 2016 . 
3. Cheo VN. Environmental Journalism in Cameroon: Trends and Auspicious Paradigm Shift. In African Humanities Review. An Interdisciplinary Journal. 2016;2(1):63-73.

4. Deuze M. What is Journalism? Professional Identity and Ideology of Journalists Reconsidered. Journalism. 2005;6(4):442-464.

5. Ryan M. Journalistic Ethics, Objectivity and Existential Journalism, Standpoint Epistemology and Public Journalism. In Journal of Mass Media Ethics. 2001;16(1):3-22.

6. Weaver DH. The Global Journalist: News People around the World. New Jersey: Hampton Press. 1998.

7. Bah TE. Interview by RN Budi. Manager of the Cameroon Baptist Convention Radio Services. Nkwen-Bamenda, Cameroon. 2019.

8. SEMA. Crisis Communication Handbook. SEMA: Jupiter Reklam AB. 2008

9. Gallagher FD. Public and Private Press in Cameroon: Changing Roles and Issues in the New Pluralism. College Semester Abroad: Cameroon, Experiment in International Living. 1991.

10. Nga NV. Information and democracy in Africa: the Cameroonian experience. Yaoundé: Editions SOPECAM. 1987.

11. Ekoudi MFM. Private press and imbalance of information in Cameroon Thesis, Department of Sociology, University of Yaoundé. 1987.

12. Ewumbue-Monono C. The Right to Inform and the 1990 Press Law in Cameroon. African Media Review. 1992;6(2):1-12.

13. Ngoh VJ. Southern Cameroons, 1922-1961: A Constitutional History Burlington, USA: Ashgate Publishing Company. 2001.

14. Rubin N. Cameroon: An African Federation. London: Pall Mall Press Limited. 1971.

15. The Unitary Constitution of Cameroon. 1972.

16. Nyamnjoh FB. How to kill an underdeveloped press: Lessons from Cameroon. In Gazette 46. Netherlands: Kluwer Academic Publishers. 1990.

17. African Commission on Human and Peoples' Rights. Cameroon's Initial Report. 1989.

18. Regional Order No. 001/AR/SDG/SG/DAAJ. 2017.

19. Betatinz. Radio Hot Cocoa in Bamenda temporarily Suspended for talking about the Strike in Southern Cameroon!. 2017.

20. Actu Cameroun. Cameroon-Media: Ban on Radio Cocoa Lifted. 2017.
21. E-Kwat TV. Peter Tabit Chi, Pidgin News Host of Radio Hot Cocoa, Bamenda was Suspended from Duty. 2018.

22. Massa E. Interview by RN Budi. Civil Servant in Bamenda, Cameroon. 2019.

23. Tarlusi TG. Interview by RN Budi. Manager of Savannah Frontier Radio, Studio 2, in Ndu, Cameroon. 2018.

24. Lamnyam H. Interview by RN Budi (Phone Discussion). Teacher and Freelance Journalist, Ndu, Cameroon. 2018.

25. The Eye Newspaper. Tribute to Fon Martin Yembe, The Journalist I knew. 2017.

26. Nchanji HN. Exclusive: My Brother Martin Fon Yembe was Assassinated. 2017.

27. Shey P. Interview by $\mathrm{RN}$ Budi. Radio Technician in Bamenda, Cameroon. 2019.

28. CPJ. Cameroon Community Radio Destroyed in Alleged Arson Attacks 2018 .

29. CPJ. Cameroon Military Court Orders Radio Journalist to be held for at least 6Months. 2018.

30. Mawe N. Interview by RN Budi. Radio Broadcaster in Bamenda, Cameroon. 2019.

31. Kaledzi I. Cameroon: Journalist Imprisoned Over Social Media Post. 2018 .

32. Journal of Cameroon. Cameroon: Journalist Mimi Mefo released from Douala Central Prison. 2018.

33. Funke D. I Spent a Month on a floor: What it's like to be imprisoned on False News Charges. 2019.

34. Gibip TB. Interview by RN. Budi. Manager. Sky FM Radio. Ndu. 2019.

35. Lyonga S. National President of CAMASEJ. Release Ambe McMillan Immediately. Press Release. 2019.

36. Cameroon News Agency. Tribute to Martin Fon Yembe. The 'Martin Luther' of Ndu. 2017.

37. Fongoh PA. Secretary-General of CAMASEJ NW "CAMASEJ NW Emergency Release. 2019.

38. Law No. The Constitution of Cameroon. 1996.

39. The African Charter on Human and Peoples' Rights. Ratified. 1989. 